\title{
The Research on the Improvement of Internal Control Quality Through the Enterprise Informatization
}

\author{
Zheng $\mathrm{Hao}^{\mathrm{a}}$, Zheng $\mathrm{Li}^{\mathrm{b}}$, Xianglong Yang ${ }^{\mathrm{c}}$ and Shi Dai ${ }^{\mathrm{d}}$ \\ College of Business \& Economics \\ The Australian National University \\ ACT, Australia \\ ahz2855628@gmail.com, bfzzinchina@gmail.com, ${ }^{\mathrm{c}}$ andy@hjgdrill.com, ${ }^{\mathrm{d}}$ sheehandai@ gmail.com
}

\begin{abstract}
The improvement of internal control quality is the key to the promotion of enterprises'management effectiveness. There are large amounts of related literatures about the relationship between the enterprises' informatization and internal control. Regrettably, the empirical study of this relationship is too scarce. First of all, based on the principle of sustainable development,the author did some researches on the theoretical background, which related to the concept of enterprises' informatization and internal control.Admittedly, this articleused the empirical method to explore the influence of informatization on the progression of internal control quality, which is basedon the data between 2009 and 2010 of the listed companies. According to the result of the study, it can be concluded thatthe companies disclosed informatization voluntarilywould obtain the higher effectively and efficiently internal control. Moreover, this article further discusses the relationship between the capital investments of informatization and the quality of internal control. Hence,it is concluded thatthe quality of internal controlcannot be promoted immediately through the capital investment on informatization.
\end{abstract}

Keywords-internal control; informatization disclosure; informatization capital investment

\section{INTRODUCTION}

With the rapid development of information technology, the progression of enterprises' informatization is inevitable and undeniable. There is little doubt that human society has already stepped into the information society and knowledge economy era. The application of modern information technology has penetrated all industries of the national economy and social advance, which is in the aspects of politics, economy and culture. In the grand goal of building a well-off society in an all-round way in 2020, Chinese government explicitly emphasize "increase informatization level greatly" and "adhere to way of the new industrialization with Chinese characteristics, informatization, urbanization and agricultural modernization" are the strategic targets of China's informatization construction and important direction guidance. Enterprises informatization is an important area of national economy informatization, which is an inevitable process of enterprises' development and has a great extent of the effects on the enterprises' operation mode, control systems, competitiveness and even management environment. Therefore, this article would empirically test whether informatization is helpful to improve the quality of internal control by file-type research method.

\section{THEORETICAL BACKGROUND}

Observing the development of rules ofthe relevant professional organizations worldwidein the field ofinformation systems' application on internal control,the Institute of Internal Auditors (IIA) published "System Control and Audit" report in 1977, which is the first report on internal control framework associated with information technology in history, focusing on information technology and business process, and risks with business automation applications. The report's content provides a feasible direction to conduct control and audit by using information technology. In 2001, American Institute of Certified Public Accountants (AICPA) issued "The announcement of auditing standards no. 94 - impacts of information technology on auditors' consideration of internal control in the audit of financial statements". The announcement particularly analyzes the high possibility thatapplicationsof information technology in the organization are likely to have a significant impact on the COSO reports. Information technology has posed great challenge to the traditional way of business, making the internal risk control present a new content and developing trend.Brad and Vandervelde (2007) apply COBIT framework in internal control and information system auditing from practice perspective; studies have found that COBIT framework predicts the auditors' actions in this field, and points out that the invention of a general theory of internal control so as to adapt to the information technology based on COBIT is the trend of the times. Marten and Johnson (2006) expound the advantage of using COBIT for IT governance, and state that using COBIT for IT governance is the direction of future study. Stoel and Muhanna (2011) study the IT technology's impact on corporate profitability and enterprise value when it is applied to the internal control, and the results show that enterprises applying IT technology to implement internal control possess significantly higher profitability and enterprise value than those which did not implement the internal control informatization.The abovementionedprofessional organizations and scholars'research results paid more attention to information technology's influence on internal auditing, information technology's effect on the internal control related to CPA financial statements auditing, IT governance and control of the COBIT framework, etc.

Chinese research on the internal control under the environment of informatization started late, but the research results areabundant, mainly reflected in the following aspects: 
Some Chinese scholars devote themselvesinto conducting research on the problems faced by internal controlunder the environment of informatization. In 1992Professor Yangpublished "accounting cybernetics", integrating the system theory, information theory and cybernetics intoaccounting, giving rise toa further development in theory and technology of accounting control. Wang (2006) states that internal control is faced withrisk from three areas due to ERP application: (1) The application of ERP needs the enterprise to carry on the business process re-engineering; lack of security of computer systems will make enterprises suffer the risk of being attacked. (2) The application of ERP software is dependent on the accuracy of the information, once information errors occur,the internal control system would probably fail; (3) The ERP system puts forward higher request for enterprises'software and hardware of internal control, which is also a huge challenge in terms of technology for enterprises. Luo and Zhang (2008) argue that informatization has a significant impact on enterprises. They continue to use the COSO report to define the five elements of internal control,make concrete analysis in the five-aspect problems of internal control in the process of enterprise informatization, and present countermeasures on the construction of internal control underenterprise informatization.

Besides,some other Chinese scholars introduce the idea of IT governance,trying to discuss the internal control problems in the informatization process from the perspective of corporate governance. Rao (2003) expounds the reasons why enough attentionshould be paid on information technology governance, and provides the framework of IT governance referred to the COBIT. Meng (2007) analyzes the three challenges Chinese enterprises must face to implement IT governance: (1) the CIO (chief information officer) lacks the knowledge and experienceof internal control; (2) the lack of systematic IT control system; (3) the existing IT control system does not have the auditability. Zhou and Chen (2008) analyze the problemsarising in the informatization of Chinese accounting management,and study the ISCA model with the help of the foreign theories and methods of information technology governance.

To sum up, the existing literatureof this filed in China is mainly focused on the internal control and auditing issues under the information technology environment,and the research methods used in the existing literature stay more on normative studies and discussions and less on the tests with empirical data. For this reason, this article focuses on the empirical tests of impacts of enterprise informatization on internal control quality, and reveals that under the current ownership structure, enterprise information is helpful to improve the quality of internal control.

\section{THEORETICAL ANALYSIS AND HYPOTHESIS}

\section{A. Information Technological Determinism and the Quality of Internal Control}

Technological determinism was the most influential genre of technological development theories until 1970s. Human society has turnedinto an information society.One of public information society theories namely "Information Technology Determinism" believes that information technology as a driving force promotes the development of society, and all aspects of the society should make adjustments in order to adapt to information technology. From the enterprise level, Lin and $\mathrm{Li}$ (2003) argue that enterprise informatization is the process that enterprises use information and communication technology to transform their business. Wang (2001) argues that information technology application inenterprise informatization mainly reflects in the production process informatization, management process informatization, office automation, and the integration system. Accordingly, enterprise informatization also motivates the adjustments of internal control system, and promotes the quality of internal control.Depending oninformation technology, themanagement structure in the enterprise internal control gets flatter,and the levels of the internal control becomes less, allowing decision makers and executors to have quicker communication and leading toclearer responsibility and higher efficiency. As a tool of risk prevention,information technology should effectively combine withbusiness activities. A qualified information system has a greater potential to reduce errors andfraud,ensuringthat enterprises'business processesare strictly in accordance with business rules. The introduction of information technology enhances the objectivity, diversity, flexibility, efficiency of enterprises'internal control andstrengthens the preventing, checking and correcting function of internal control.The information systemswith the characteristics of opening, timeliness and electronization, prompt information demanders to communicatetimely and effectively and realize continuous real-time monitoring. Therefore, on the surface, the influence of informatization on the internal control is the influence on the means and methods; the deeper influence is on thetargets of enterprises. Moreover, the degree of the achievement of internal control goals reflects the quality of the internal control. Therefore hypothesized:

H1: In the case of other conditions unchanged, the companies with disclosure of informatization have higher quality of the internal control.

\section{B. The Scale of Enterprise Information Investment and the Quality of Internal Control}

Promoting enterprises'independent innovations and technological upgrading is one of China'snationalinnovationstrategies, research and development ability not only decides the survival and core competitiveness of enterprises,but also is an important reflection of a country's comprehensive economic power and development potential.R\&D investmentsand construction in enterprise informatizationdetermine the degree of informatization; Chinese government encourages enterprises informatization construction by the government subsidy and other supportive policies.Therefore, whether an enterprise is usingthe government subsidy policies, how much the government subsidyis used andthe investment scale of its own funds in informatization, affect theenterprise's informatization process and the informatization degree of each element of internal control,which finally impacts the quality of internal control. Considering the time delay, informatization inputs wouldnot improve the quality of internal control of the same year, even would lower the internal control quality when the informatization projects fail.Therefore hypothesized: 
H2: In the case of other conditions unchanged, the enterprise informatization project investment amount is not positivelyto the quality of internal control.

\section{RESEARCH DESIGN}

\section{A. Research Samples and Data Sources}

Based on the data of 2422 listed companies in 2009, after deleting data-missing samples, the article keeps 995 samples as the empirical test samples. The internal control indexesof 2009 and 2010are chosen from "DiBo • China's listed company internal control index". The design of "DiBo •China's listed company internal control index" is mainly based on related Chinese norms of internal control such as "Basic internal control norms for enterprises", "The guidance for enterprises internal control" and other international internal control systems. Index designingalso draws lessons from existing research results of internal control index at home and abroad, and follow the constructionmethodofan economic index. On the basis of above systems and methods, the design of DiBo indexesdepends on the completion degree of the five major goals which are legal compliance, adequacy of internal control reports, asset security, operational efficiency and strategic realization, and the actual situation of implementing the internal control in listed companies in China, which makes DiBo indexesthe most authoritative indexes to comprehensively reflect the levels of the internal control and the risk management capacity of listed companies. Theinformatizationdisclosureof these 1002 sample enterprises is mainly through manual collection and reading the annual internal control reports and other relevant information extractedfrom the board of directors, which is measured by 1-0 variable. Other variable data, such as the proportion of the first largest shareholder and the firm size, mainly come from the Guotaian CSMAR database.

\section{B. Variables Design}

\section{1) Dependent variable: Quality of Internal Control}

Internal control quality reflects the process quality and implementation effectivenessof internal control,ultimately reflecting the extent to achieve the goal of internal control. High internal control qualitymeans that realization degree of the internal control goal is high, and vice versa. DiBo index is a measuring tool reflecting the degree of realization of internal control internal control goal, and can be used as a substitution variablefor the quality of internal control. DiBo China's listed companies internal control index system originated from a Chinese key accounting research subject "index of listed Chinese internal control research". The design of DiBo China's listed company internal control index system is based on "Enterprises internal control basic norms"published by Chinese government.The design of index draws lessons fromthe related domestic and foreign research achievements, and follows the general procedures and methods ofindexconstruction, which can comprehensively reflect the quality of the enterprises' internal control.

SinceDiBo internal control index is the most authoritative and the most comprehensive data to reflect the implementation of the norms of the internal control in the listed companies in
China,it is reasonable for this paper to choose DiBo internal control index as a dependent variable.

\section{2) Independent Variable: Status of Enterprise} Informatization

Qiu (2006) argues that enterprise informatization involves personnel of every level in an enterprise, including senior managers, middle managers, and other staff members; their skills and awareness of informatizationwill affect the investment of enterprise informatization. Generally speaking, the stronger the awareness of enterprise informatization they have, the higher the level of enterprise informatization will be. The construction of Chinese enterprises'informatizationstarted relatively lateand the speed of the construction is slow, therefore it needs to go through a few years or even decades of expansion and integration to form a complete system. If the managers of an enterprise have strong consciousness of enterprise informatization and takeenterprise informatization into their future enterprise strategic planning, the enterprise informatization investment andthe related information of informatization construction will be disclosed in time in the annual reports, leading to an efficiency improvement of internal control and management. Consequently, this article will take the disclosure status of informatization as an explanatory variable to measure the managers' attention on informatization.

The informatization status of an enterprise can also be measured by the subsidies from the government.Chinese government encourages the construction of enterprise informatization and enterprises'independent research on informatization by the form of government subsidies to realize the promotion of enterprise's automation, hence improving the efficiency of internal control and management. Therefore, this article uses the scale of government subsidies as a substitution variable of the degree of enterprises'informatization investment.

\section{3) Control Variables : Ownership Structure, Enterprise} Scaleetc

Enterprise internal control system originates from the principal-agent problem due to the separation of management and ownership in the modern enterprise system. Within the framework of the principal-agent relationship, internal controlis ameans to reduce the agency costs. Therefore, equitystructure affects the quality of the enterprise internal control (Wuet al., 2009). This paper takesthe proportion of thelargest shareholder's shareholding as the substitution variable of ownership structure. The scale of the enterprisesis presented by the scaleof their static assetsand dynamic operating income, and the net increment of the intangible assets also has an impact on the quality of internal control. Therefore, this article will use themas control variables. 
TABLE I. MEASURES AND DEFINITIONS OF VARIABLES

\begin{tabular}{|c|c|c|c|}
\hline $\begin{array}{c}\text { Variable } \\
\text { type }\end{array}$ & $\begin{array}{c}\text { Variable } \\
\text { name }\end{array}$ & Measures & Definitions \\
\hline $\begin{array}{l}\text { Dependent } \\
\text { variables }\end{array}$ & DIB & $\begin{array}{l}2010 \mathrm{DiBo} \\
\text { internal control } \\
\text { index }\end{array}$ & $\begin{array}{l}\text { Internal control quality of A- } \\
\text { share listed companies in } \\
\text { Chinain } 2009 \text { issued by DiBo. }\end{array}$ \\
\hline \multirow{2}{*}{$\begin{array}{l}\text { Independent } \\
\text { variables }\end{array}$} & Infor10 & $\begin{array}{l}\text { Disclosure of } \\
\text { informatization }\end{array}$ & $\begin{array}{l}\text { Whether there is information } \\
\text { disclosure in } 2009 \text { annual } \\
\text { report, the disclosed is } 1 \text {, the } \\
\text { undisclosed is } 0 .\end{array}$ \\
\hline & Xxhtre & $\begin{array}{l}\text { Investment } \\
\text { amount of } \\
\text { informatization }\end{array}$ & $\begin{array}{c}\text { Informatizationinvestment } \\
\text { amount disclosed by } 2009 \\
\text { annual reports of sample } \\
\text { companies }\end{array}$ \\
\hline \multirow{4}{*}{$\begin{array}{l}\text { Control } \\
\text { variables }\end{array}$} & Bigshare & $\begin{array}{l}\text { Proportions of } \\
\text { the largest } \\
\text { shareholder's } \\
\text { shareholding } \\
\end{array}$ & $\begin{array}{c}\text { Proportions of } \\
\text { thelargestshareholder's } \\
\text { shareholding of } 2009 \text { sample } \\
\text { companies }\end{array}$ \\
\hline & Lsize & Enterprise scale & $\begin{array}{l}\text { The natural logarithm of final } \\
\text { total assets of } 2009 \text { sample } \\
\text { companies }\end{array}$ \\
\hline & Income & $\begin{array}{l}\text { Operating } \\
\text { income }\end{array}$ & $\begin{array}{l}\text { Total operating revenue of } \\
\text { sample companies in } 2009\end{array}$ \\
\hline & Netinv & $\begin{array}{c}\text { Incrementof } \\
\text { intangible assets }\end{array}$ & $\begin{array}{l}\text { The difference between the } \\
\text { beginning and the ending } \\
\text { amount of intangible assets of } \\
2009 \text { sample companies }\end{array}$ \\
\hline
\end{tabular}

\section{Model Design}

This paper makes adjustments to the models used in the previous research, thus establishinga new regression model as follows:

\section{DIB $=\beta_{0}++\beta_{1}$ Infor 10 $+\beta_{2}$ Xxhtre $+\beta_{3}$ Bigshare + $\beta_{4}$ Lsize $+\beta_{5}$ Income $+\beta_{6}$ Netinv $+\varepsilon$}

\section{THE EMPIRICAL TEST AND ANALYSIS RESULTS}

\section{A. Descriptive Statistics}

According to table II, among 995 sample companies, 476 companies' annual reports have disclosed the information of informatization construction, including 114 companies clearly disclosingtheir investment scale of company informatization construction, while other onesout of 476 companies have made qualitative description about their informatization construction. In $2009,48 \%$ of the sample companies disclosed information of informatization, with an average of 180,000 RMB. In 2010, it published that the mean value of the samples'company internal control indexes is 702.03; the maximum value is 958.99, and the minimum value of 255.53. Moreover, the proportion of the first largest shareholder's shareholdingaveragesout at $37 \%$ in 2009. All these results illustrate that theownership of the sample companies are concentrated, and the average quality of internal control is relatively high.

\section{B. Correlation Test and Analysis}

Correlation test in table II shows that the information disclosure of informatization construction and the asset sizehave a significant positive correlation with the company's internal control at $1 \%$ level,and they also have a significant positive correlation with the proportion of company's largest shareholder holding at 5\% level. Except that intangible asset increment and 2010 DIB are not correlated significantly, information disclosure, asset scale, the proportion of the largest shareholder's shareholding and operating income are all significantly and positively correlated with the internal control quality at $1 \%$ level in 2009. This is consistent with our hypothesis.The correlation coefficients between explain variables and control variables are less than 0.50, and the results of multicollinearity test testing show that collinearity does not exist between the variables.

\section{Multiple Regression Results and Analysis}

In table III, model 1 regression results show that the adjusted $\mathrm{R} 2=0.248$, indicating that model 1 has a relatively good fitting effect. In model $1, \mathrm{~F}=66.824$, and the overall model 1 passes the $\mathrm{F}$ test; besides, variance inflation factors of each variable are less than 2 , which shows that there is no serious collinearity between variables. These statistics show that the analytical basis of the regression results is credible. So the results of model 1 can be summarized as follows: without considering the informatization input amount, the disclosure of enterprises' informatization construction has a positive impact on the quality of internal control, and the correlation between them is significant at $1 \%$ level.In conclusion, the development of informatization construction in enterprises will promote improvement of the internal control quality. So hypothesis 1 has passed the validation.

In table III, model 2 regression results show that the adjusted $\mathrm{R} 2=0.268$, indicating that the model 2 has a relatively good fitting effect. In model $2, \mathrm{~F}=73.878$, and the overall model 2 passes the $\mathrm{F}$ test; besides, variance inflation factors of each variable are less than 2 , which shows that there is no serious collinearity between variables. These statistics show that the analytical basis of the regression results is credible. So the results of model 2 can be summarized as follows: the investment of enterprises' informatization has a negative impact on the quality of internal control, and the correlation between them is significant at $1 \%$ level. Inconclusion,more investment in enterprises' informatization construction does not mean higher quality of internal control. So hypothesis 2 has passed the validation.

In table III, model 3 regression results show that the adjusted $\mathrm{R}^{2}=0.144$, indicating that model 3has a relatively good fitting effect.In model $3, \mathrm{~F}=34.587$, and the overall model 3 passes the $F$ test; besides, variance inflation factors of each variable are less than 2 , which shows that there is no serious collinearity between variables. These statistics show 
TABLE II. THE DESCRIPTION STATISTICS AND CORRELATION

\begin{tabular}{|c|c|c|c|c|c|c|c|c|c|c|c|c|}
\hline & $\mathbf{N}$ & Minimum & Maximum & Average & $\begin{array}{l}\text { Standard } \\
\text { deviation }\end{array}$ & DIB & Infor10 & Xxhtre & Bigshare & Lsize & Netinv & INcome \\
\hline DIB & 995 & 255.53 & 958.99 & 702.02 & 83.83 & 1 & & & & & & \\
\hline Infor 10 & 995 & 0 & 1 & .48 & .500 & $.117^{* *}$ & 1 & & & & & \\
\hline Xxhtre & 995 & 0 & $15.05 \mathrm{E} 8$ & 1831735.06 & 4.77E7 & $.064^{*}$ & .040 & 1 & & & & \\
\hline $\begin{array}{l}\text { Bigsha } \\
\text { re }\end{array}$ & 995 & 4.49 & 85.23 & 36.96 & 15.73 & $.159^{* * *}$ & $.079^{*}$ & $.083^{* *}$ & 1 & & & \\
\hline Lsize & 995 & 18.27 & 29.80 & 21.82 & 1.38 & $.495^{* * *}$ & $.123^{* *}$ & $.145^{* *}$ & $.207^{* *}$ & 1 & & \\
\hline Netinv & 995 & $-1.99 \mathrm{E} 9$ & $1.78 \mathrm{E} 10$ & $6.88 \mathrm{E} 7$ & $6.27 \mathrm{E} 8$ & .054 & .055 & $.334^{* *}$ & $.101^{* *}$ & $.206^{* * *}$ & 1 & \\
\hline $\begin{array}{l}\text { INcom } \\
\mathrm{e}\end{array}$ & 995 & .00 & $1.34 \mathrm{E} 12$ & $5.56 \mathrm{E} 9$ & $3.86 \mathrm{E} 10$ & $.175^{* *}$ & .051 & $.463^{* *}$ & $.133^{* *}$ & $.265^{\text {*** }}$ & $.349^{* * *}$ & 1 \\
\hline
\end{tabular}

Note: ** means at the $1 \%$ level, description statistics are significantly correlated (double side).

* means at the $5 \%$ level, description statistics are significantly correlated (double side).

TABLEIII. THE DESCRIPTION STATISTICS AND CORRELATION

\begin{tabular}{|c|c|c|c|c|c|}
\hline Independent Variables & $\begin{array}{l}\text { Model } 1 \\
\text { Independent } \\
\text { Variables: } \\
\text { 2010DIB }\end{array}$ & $\begin{array}{l}\text { Model } 2 \\
\text { Independent } \\
\text { Variables: } \\
\text { 2010DIB }\end{array}$ & $\begin{array}{l}\text { Model } 3 \\
\text { Independent } \\
\text { Variables: } \\
\text { 2011DIB }\end{array}$ & $\begin{array}{l}\text { Model } 4 \\
\text { Independent } \\
\text { Variables: } \\
\text { 2011DIB }\end{array}$ & $\begin{array}{l}\text { Model } 5 \\
\text { Independent } \\
\text { Variables: } \\
\text { Average of } 2010 \\
\text { and } 2011 \text { DIB }\end{array}$ \\
\hline & Coefficient & Coefficient & Coefficient & Coefficient & Coefficient \\
\hline Constant & 34.125 & $144.373^{* * *} *$ & $265.919 * * *$ & $390.318 * * *$ & $150.022 * * *$ \\
\hline Infor 10 & $\begin{array}{l}9.336 * * \\
(4.595) \\
\end{array}$ & - & $\begin{array}{l}6.081 \\
(4.581) \\
\end{array}$ & - & $\begin{array}{l}\text { 7. } 709 * * \\
(3.866) \\
\end{array}$ \\
\hline Xxhtre & - & $\begin{array}{l}-1.135 \mathrm{E}-6^{* * *} \\
(.000) \\
\end{array}$ & - & $\begin{array}{l}-1.236 \mathrm{E}-6^{* * *} \\
(.000) \\
\end{array}$ & - \\
\hline Bigshare & $.290 *$ & .215 & .246 & .152 & $.268 * *$ \\
\hline Lsize & $30.017 * * *$ & $25.050^{* * * *}$ & $18.985 * * *$ & $13.316^{* * *}$ & $24.501 * * *$ \\
\hline Netinv & $-1.115 \mathrm{E}-8^{* * * *}$ & $-1.158 \mathrm{E}-8^{* * *}$ & $-4.714 \mathrm{E}-9$ & $-5.278 \mathrm{E}-9$ & $-7.931 \mathrm{E}-9 * *$ \\
\hline INcome & $1.069 \mathrm{E}-10^{*}$ & $1.342 \mathrm{E}-9 * * *$ & $2.211 \mathrm{E}-10^{* * *}$ & $1.566 \mathrm{E}-9 * * *$ & $1.640 \mathrm{E}-10^{* * *}$ \\
\hline $\mathrm{N}$ & 995 & 995 & 995 & 995 & 995 \\
\hline $\mathrm{F}$ & 66.824 & 73.878 & 34.587 & 42.978 & 68.611 \\
\hline Adj. $\mathrm{R}^{2}$ & 0.248 & 0.268 & 0.144 & 0.174 & 0.253 \\
\hline
\end{tabular}

Note: The numbers in the brackets represent standard deviations. *,** and *** mean the correlation is significant at the level of $10 \%, 5 \%$ and $1 \%$ respectively

that the analytical basis of the regression results is credible. So the results of model 3 can be summarized as follows: without considering the informatization input amount, the disclosure of enterprises' informatization construction has a positive impact on the quality of internal control of the next year, but the correlation between them is not significant. In conclusion, the disclosure of enterprises' informatization has a limited promotion on enterprises' internal control quality of the next year. So hypothesis 1 has passed the validation.

In table III, model 4 regression results show that the adjusted $\mathrm{R} 2=0.174$, indicating that model 4 has a relatively good fitting effect. In model $4, \mathrm{~F}=42.978$, and the overall model 4 passes the $\mathrm{F}$ test; besides, variance inflation factors of each variable are less than 2 , which shows that there is no serious collinearity between variables. These statistics show that the analytical basis of the regression results is credible. So the result of model 4 can be summarized as follows: the investment of enterprises' informatization has a negative impact on the quality of internal control of the following year, and the correlation between them is significant at $1 \%$ level. Inconclusion, more investment in enterprises' informatization construction does not mean higher quality of internal control. The failure of informatization projects in the current year may have a negative effect on the internal control of the following year. So hypothesis 2 has passed the validation.

\section{Robustness Test}

In the regression model,the average DIB of 2010 and 2011 is taken as a substitution variableof the dependent variable. In 
table 3, the model 5regression results show that the model has good robustness. At the same time, regression results show that the model is still robust when taking the company's operating income as a substitution variable of company'sscale.

\section{CONCLUSIONS AND RECOMMENDATIONS}

The internal control qualityis the crux of the internal control system construction, which means the higher of internal control quality could assist the achievement of the internal control purpose. This paperpoints out that the informatization environmentcould affect the internal environment and the communication effectiveness; thus, affects the quality of internal control.The empirical data of the listed companies in China between 2009 and 2010 was selected as the research sample.According to theempirical testresults of the three hypotheses, the companies that make a disclosure of informatization would have a higher quality of internal control when the other conditions do not change. However,the investment amountsof informatization could notimprove theinternal control quality directlyin this year and the next year, which indicatesthe negative relationship between the internal controlquality and the informatization investment. In addition,it can be conclude that thelargest shareholder's security amounts of the firm that had informatization disclosurehavea positive impact on the internal control qualityparticularly significant atthe $1 \%$ level.

Based on the above conclusion, the promotion of internal controlquality can be done through the recommendations from three levels: In the macro, Chinese government should encourage and supportthe enterprises' informatization constructionby increasing in allocating fund. In the meso, the enterprises should accelerate the evolution of the informatization and enlarge the scale of its construction to obtain the strength of industry competition. In the micro, the auditorsshould boost the supervision and instruction of enterprises' informatization disclosure. Only after the thorough implementation of these three levels' suggestion can enterprises' internal control quality be enhanced continuously.

\section{REFERENCES}

[1] Brad, T. and Scott, D. V. (2007). An empirical examination of CobiT as an internal control framework for informatization.International Journal of Accounting Information Systems, 8(4), 240-263.

[2] Asa, L., Pontus, J., Erik, J., Mathias, E. and Marten, S. (2006). A survey on CIO concerns-do enterprise architecture frameworks support them? Information Systems Frontiers, 8(2), 81-90.
[3] Dale, S.M. and Waleed, A. M. (2011). IT internal control weaknesses and firm performance : An organizational liability lens. International Journal of Accounting Information Systems, 12(4), 280-304.

[4] Yang, Z. C. (1992). Accounting control theory,Shang Xi: Xi 'an jiaotong university press

[5] Wang, Q. (2006). Study of enterprise internal control under the ERP environment. Liao Ning:Northeast university of finance and economics.

[6] Luo, L. B. (2008). Research of the internal control problems in the process of enterprise informatizaion. Accounting Research, 5, 69-75.

[7] Rao, Y. C. (2003). A new perspective of corporate governance : IT governance-the relationshipbetween establishmentof business goals and information technology. Accounting Research, 8, 23-26.

[8] Zhou, C. L. and Chen, B. F. (2009). ISC model: analysisfromIT governance perspective. Accounting Research,2,61-67.

[9] Liu, Z. Y. and Liu, J. (2001). Enterprises' internal control under new technology. Accounting Research,12,24-25.

[10] Yang, Z. N. (2003). ISCA model of management accounting informatization. Accounting Research,10,21-22.

[11] Yan, D. W. and Zhang, R. J. (2003). New accounting control theory real-time control study. Accounting Research,4,15-16.

[12] Shi, A. Z. (2006). Researchon the development of internal control from the history of internal control-improvement of internal control informatizaion. Auditing Research,2,3-7.

[13] Tao, L. J. (2009). Research on internal control of China's financial reportingunder the IT environment. Fu jian: Xiamen university.

[14] Pan, Y. and Ou, L. Y. (2010).Construction of the framework of IT's embedment in enterprise internal control. Journal of fuzhou university, 6 , 20-26.

[15] Guo, Q. and Hu, J. (2010).Study on the relationship between internal control and enterprise informatization. Journal of Guangxi college of finance and economics, 6, 71-75.

[16] Zhang, T. J. and Lv, B. L. (2010). Research on Informatization innovation, internal control and operation risk control. Soft science, 12 $13-18$.

[17] Han, X. M. and Lu, J. (2012). Enterprise informatizaion and internal control: an theory model of interactive promotion. Financial accounting, $12,21-23$

[18] Wang, Z. T. (2001). Enterprise informatization and management reform. Peiking: Press of Renmin university of China.

[19] Lin, Y. F. and Li, Y. J. (2003). Enterprise informatization and enterprise competitiveness. Peiking: China economic research center of Peking University.

[20] Qiu, C. B., Shi, M. and Zhang, J. (2006). The typical correlation analysis of key influence factors of enterprise informatization. Journal of Gilin University, 24, 525-542.

[21] Wu, Y. B., Liao, Y. G. and Lin, B. (2009). The analysis of the influence on the quality of internal control of ownership structure - based on the test of data of internal control information of listed companies in 2007. Modern finance and economics, 9, 10-114. 